\title{
Intrapleural therapy in management of complicated parapneumonic effusions and empyema
}

\author{
AlaEldin $\mathrm{H}$ Ahmed ${ }^{1,2}$ \\ Tariq E Yacoub ${ }^{2}$ \\ 'Department of Medicine, Faculty \\ of Medicine, University of Khartoum, \\ ${ }^{2}$ Department of Respiratory Medicine, \\ Elshaab Teaching Hospital, Khartoum, \\ Sudan
}

This article was published in the following Dove Press journal:

Clinical Pharmacology: Advances and Applications

18 November 2010

Number of times this article has been viewed
Abstract: Empyema thoracis causes high mortality, and its incidence is increasing in both children and adults. Parapneumonic effusions (PPEs) develop in about one-half of patients hospitalized with pneumonia, and their presence increases mortality by about four-fold. PPEs can be divided into simple PPEs, complicated PPEs, and frank empyema. Two guideline statements on the management of PPEs in adults have been published by the British Thoracic Society (BTS) and the American College of Chest Physicians; a third guideline statement published by the BTS focused on management of PPEs in children. The two adult guideline statements recommend drainage of the pleural space in complicated PPEs and frank empyema. They also recommend the use of intrapleural fibrinolysis in those who do not show improvement. The pediatric guideline statement recommends adding intrapleural fibrinolysis to those treated by tube thoracostomy if they have loculated pleural space or thick pus. Published guideline statements on the management of complicated PPEs and empyema in adults and children recommend the use of intrapleural fibrinolysis in those who do not show improvement after pleural space drainage. However, published clinical trial reports on the use of intrapleural fibrinolysis for the treatment of pleural space sepsis suffer from major design and methodologic limitations. Nevertheless, published reports have shown that the use of intrapleural fibrinolysis does not reduce mortality in adults with parapneumonic effusions and empyema. However, intrapleural fibrinolysis enhances drainage of infected pleural fluid and may be used in patients with large collections of infected pleural fluid causing breathlessness or respiratory failure, but a proportion of these patients will ultimately need surgery for definite cure. Intrapleural streptokinase and urokinase seem to be equally efficacious in enhancing infected pleural fluid drainage in adults. In most of the published studies in adults, the use of intrapleural fibrinolysis was not associated with serious side effects. There is emerging evidence that the combination of intrapleural tissue plasminogen activator (tPA) and deoxyribonuclease (DNase) is significantly superior to tPA or DNase alone or placebo in improving pleural fluid drainage in patients with pleural space infection. In children, intrapleural fibrinolysis has not been shown to reduce mortality, but has been shown to enhance drainage of the pleural space and was safe. In addition, two prospective, randomized trials have shown that intrapleural fibrinolysis is as effective as video-assisted thoracoscopic surgery for the treatment of childhood empyema and is a more cost-effective treatment and therefore should be the primary treatment of choice.

Keywords: parapneumonic effusions, empyema, intrapleural fibrinolysis, intrapleural DNase

\section{Introduction}

Empyema thoracis has been recognized since ancient times, and in spite of modern therapeutic interventions is still a cause of high mortality. ${ }^{1}$ In recent years, the incidence of empyema has been increasing in both children and adults, and the cause of this 
surge remains unknown. ${ }^{2}$ Most cases of empyema complicate either community- or hospital-acquired pneumonia, but some develop without pneumonia, ie, so-called primary empyema, and a proportion are iatrogenic. Parapneumonic effusions (PPEs) develop in up to $57 \%$ of patients hospitalized with bacterial pneumonias. ${ }^{3-5}$ The presence of PPEs increases mortality in these patients by about three- to six-fold. ${ }^{4,6}$

\section{Pathophysiology of parapneumonic effusions}

The American Thoracic Society described three stages in the natural course of empyema, ie, the exudative, fibrinopurulent, and organizing phases. ${ }^{7}$ In the exudative phase, pleural fluid is derived from pulmonary interstitial fluid that is associated with lung infection and inflammation. This fluid crosses the visceral pleura and accumulates in the pleural space and is usually not infected. The clinical correlates of the exudative phase are simple PPEs. Simple PPEs have characteristic biochemical and microbiologic features, namely $\mathrm{pH}>7.2$, lactate dehydrogenase $<1000 \mathrm{IU} / \mathrm{L}$, glucose $>2.2 \mathrm{mmol} / \mathrm{L}$, and no organisms in culture or Gram stain. Treatment of simple PPEs with antibiotics is likely to be adequate, and there is no need for pleural fluid drainage. ${ }^{8}$

Complicated PPEs are clinical correlates of the fibrinopurulent stage. A critical characteristic of the fibrinopurulent stage of pleural sepsis is disturbance of the physiologic equilibrium between clotting and fibrinolysis within the pleural space. ${ }^{9}$ Bacterial invasion across the damaged endothelium accelerates the immune reaction, promoting further migration of neutrophils and activation of the coagulation cascade, leading to increased procoagulant and depressed fibrinolytic activity. ${ }^{10,11}$ Several mediators for the activation of the coagulation cascade and inhibition of fibrinolysis have been suggested. Tumor necrosis factor alpha, for example, has been shown to stimulate the release of tissue plasminogen activator (tPA) inhibitors from pleural mesothelial cells. It has been shown that there are increased levels of tPA-2 and depressed levels of tPA during complicated pleural sepsis. ${ }^{12}$ Although the exact mechanisms behind the procoagulant state still need to be elucidated, their effects are well known, ie, pleural surfaces coated with fibrin and fibrin strands with secondary adhesions and loculations, and all of these lead to impeding of pleural fluid drainage. The inflammatory process continues, fueled by more bacterial death and phagocytosis. ${ }^{10}$ This combination of events leads to increased lactic acid production, causing a drop in pleural fluid $\mathrm{pH},{ }^{13}$ increased glucose consumption, and a rise in lactate dehydrogenase levels resulting from leukocyte death. All of these lead to the characteristic biochemical and microbiologic changes of complicated pleural effusions, namely $\mathrm{pH}<7.20$, glucose $<2.2 \mathrm{mmol} / \mathrm{L}$, lactate dehydrogenase $>1000 \mathrm{IU} / \mathrm{L}$, and possible positive Gram stain and/or bacterial culture. If left untreated, complicated PPEs progress to overt pus (empyema).

The fibrinopurulent stage is followed by the organizing phase, in which there is proliferation of fibroblasts. ${ }^{10} \mathrm{~A}$ solid pleural peel replaces the soft fibrin, preventing lung reexpansion, causing lung function impairment, and creating a persistent pleural space.

\section{Guidelines for management of parapneumonic effusions}

Two guideline statements on the management of PPEs in adults have been published by the American College of Chest Physicians (ACCP) and the British Thoracic Society (BTS). ${ }^{14,15}$ The two statements reflect different approaches to the management of PPEs. However, they agree that all complicated PPEs and frank pleural space pus should be drained and that patients who do not improve on this treatment may receive intrapleural fibrinolysis or be referred for surgical drainage or decortication..$^{14,15}$

A third guideline statement on the management of PPEs in children has been published by the BTS. ${ }^{16}$ In this document, the management of PPEs is planned according to an algorithm and recommends that all children with PPEs should receive either medical treatment in the form of chest tube drainage with pleural fluid sampling for microbiology at the same time as chest tube insertion or early surgery in the form of video-assisted thoracoscopic surgery (VATS) or minithoracostomy. For those who are treated medically, if they are noted to have a loculated pleural space or thick pus, they should be candidates for intrapleural fibrinolysis. If patients do not improve after intrapleural fibrinolysis, they should be referred for late surgery. ${ }^{16}$ In spite of these recommendations, the level of evidence for the use of intrapleural fibrinolysis is low. ${ }^{14-16}$ This paper provides a critical review of the existing literature on the use of intrapleural fibrinolytic therapy for complicated PPEs and empyema. It also reviews emerging evidence on adding DNase to intrapleural fibrinolysis in managing complicated PPEs and empyema. Articles included in the review were identified by conducting a Medline search in April 2010. The search terms were "empyema" and "parapneumonic effusion", each linked to "fibrinolysis", "streptokinase", "urokinase", and "tissue plasminogen activator". Articles were restricted to the English language. The reference lists of Medline-retrieved articles 
were reviewed for titles of other possibly relevant articles. All articles (controlled or uncontrolled) that used any of the fibrinolytic drugs, ie, streptokinase, urokinase, and tPA, in the treatment of PPEs or empyema in adults and children were included in the review.

\section{Mechanism of action of fibrinolytic drugs}

Fibrinolytic drugs vary in their mechanism of action. tPA induces fibrinolysis of the formed thrombus by preferentially activating plasminogen bound to fibrin and does not activate systemic plasminogen. ${ }^{17}$ Streptokinase combines with circulating plasminogen to form an activation complex, which causes limited proteolysis of other plasminogen molecules to plasmin. Streptokinase activates the conversion of plasminogen (profibrinolysin) into plasmin (fibrinolysin), which stimulates the conversion of fibrin (insoluble) into fibrin fragments (soluble). ${ }^{18}$ Urokinase is also fibrin-selective and is converted to urokinase from prourokinase upon binding to fibrin. It directly converts plasminogen into plasmin. ${ }^{19}$ All three drugs have been used in trials of intrapleural fibrinolysis in adults and children.

\section{Intrapleural fibrinolytic therapy in adults}

Intrapleural fibrinolytic treatment of pleural space sepsis was first described in 1949 when Tillett and Sherry published their seminal article on this subject using streptokinase. ${ }^{20}$ Since their publication, 28 studies on the use of intrapleural fibrinolytic therapy for pleural space sepsis in 1280 adults have been published, and these reports are summarized in Table $1 . .^{21-48}$

Published studies in adults employed intrapleural urokinase and streptokinase as fibrinolytic agents. Streptokinase on its own was used in 16 studies, ${ }^{21-23,25,26,28,29,32,35,38,39,42-44,46,48}$ whereas one study used either streptokinase or urokinase. ${ }^{36}$ Another controlled study of 44 patients compared streptokinase with normal saline and showed that the use of streptokinase resulted in a higher success rate and reduced surgical referral ${ }^{47}$ Intrapleural urokinase on its own was used to treat pleural space sepsis in eight studies. ${ }^{24,27,30,31,33,34,37,45}$ Two studies compared intrapleural urokinase with streptokinase in the treatment of pleural space infection. ${ }^{40,41}$ Bilacerogula et al randomized 128 patients with pleural space sepsis to receive intrapleural streptokinase, urokinase, or saline. The group that received urokinase showed better radiologic clearance and drained more fluid. ${ }^{40}$ However, a similar study that included 50 patients has shown streptokinase and urokinase to be equally efficacious in treating pleural space infection.
The studies of intrapleural fibrinolysis for the treatment of empyema and PPEs in adults suffer from three major limitations. First, most of these studies are uncontrolled observational reports, the methodic limitations of which are well known. ${ }^{21-39}$ Second, they did not have the statistical power to measure primary endpoints of clinical interest, such as patient mortality, need for surgery, and residual lung volume. ${ }^{21-33,35-39,41-46}$ Third, in many of the published reports, the principal endpoint was an increase in pleural fluid drainage. ${ }^{21,23-29,32,34,37-43,45}$ The amount of pleural fluid drained is not always an ideal clinical outcome measure because, in animal studies, streptokinase has been shown to induce pleural fluid accumulation. ${ }^{49}$ Therefore, enhanced pleural fluid drainage should either translate into improved clinical outcome or reduced mortality to be an ideal endpoint. Of the published work in adults, increased pleural fluid drainage resulted in greater improvement in lung expansion or clinical improvement, radiologic improvement, or reduced morbidity in five studies. ${ }^{24,38,40,43,45}$ Of these five studies, three were controlled trials. ${ }^{40,43,45}$ Furthermore, there was partial improvement in lung expansion, clinical status, radiologic appearance, or reduced morbidity in seven studies. ${ }^{21,23,28,29,32,37,41}$ Of these, only one study was controlled. ${ }^{41}$ However, it is important to note that the amount of pleural fluid drained did not translate into reduced mortality in the two studies that assessed volume of pleural fluid drained and mortality as endpoints, although both were controlled trials. ${ }^{42,47}$ In fact, only one study has shown that streptokinase and early surgical drainage was associated with reduced mortality when compared with streptokinase and tube drainage. This study was controlled and included 82 patients. ${ }^{46}$ The use of intrapleural fibrinolysis in adults was found to be safe in 13 studies, ${ }^{21,24,26,27,29-31,34,36-39,43}$ of which one was controlled. ${ }^{43}$ Only one study has shown that serious adverse events, including chest pain, fever, or allergy, were more common in those who received streptokinase, and this study was controlled. ${ }^{48}$

The largest published controlled study on the use of intrapleural fibrinolytic therapy for the treatment of pleural space sepsis deserves special discussion. This is a recently published UK, multicenter, double-blind trial including 454 patients with pleural infection. ${ }^{48}$ Patients were randomly assigned to receive either streptokinase 250,000 $\mathrm{U}$ twice daily or placebo for three days. The primary endpoints were death or need for surgical drainage at three months. The secondary endpoints were rates of death and surgery (analyzed separately), radiographic outcome, and length of hospital stay. There was no significant difference between the groups who received streptokinase or placebo 
Table I Summary of intrapleural fibrinolysis trials in adults

\begin{tabular}{|c|c|c|c|}
\hline Reference & Type of study & $\begin{array}{l}\text { Patients }(n) \text {, } \\
\text { agent used }\end{array}$ & Outcome \\
\hline Bergh et $\mathrm{al}^{21}$ & Cohort, single-center & 38, streptokinase & $\begin{array}{l}\text { Increased pleural fluid drainage in all patients; } \\
\text { lung re-expansion in } 79 \% \text { of patients; safe }\end{array}$ \\
\hline Fraedrich et $\mathrm{a}^{22}$ & Retrospective & $\begin{array}{l}27, \text { streptokinase and } \\
\text { streptodornase }\end{array}$ & $44 \%$ of patients were cured \\
\hline Mitchell et $\mathrm{al}^{23}$ & $\begin{array}{l}\text { Retrospective review } \\
\text { of cases }\end{array}$ & 9, streptokinase & $\begin{array}{l}\text { Increased pleural fluid drainage in } 67 \% \text { of patients, } \\
\text { but treatment was successful in } 44 \% \text { of patients only }\end{array}$ \\
\hline Moulton et $\mathrm{al}^{24}$ & $\begin{array}{l}\text { Cohort study, } \\
\text { single-center }\end{array}$ & II, urokinase & $\begin{array}{l}\text { Successful in } 92 \% \text { of patients causing complete } \\
\text { drainage of pleural space fluid; safe }\end{array}$ \\
\hline Willsie-Ediger et $\mathrm{a}^{25}$ & Case reports & 3 , streptokinase & $\begin{array}{l}\text { Successful in causing prompt pleural fluid } \\
\text { drainage in all } 3 \text { patients }\end{array}$ \\
\hline Aye et $\mathrm{al}^{26}$ & Cohort, single-center & 14, streptokinase & Increased pleural fluid drainage in $93 \%$ of patients; safe \\
\hline Lee et $\mathrm{al}^{27}$ & Cohort, single-center & 10, urokinase & $\begin{array}{l}\text { Complete drainage of pleural space was accomplished } \\
\text { in } 90 \% \text { of patients; safe }\end{array}$ \\
\hline Henke et $\mathrm{a}^{28}$ & Cohort, single-center & 12, streptokinase & $\begin{array}{l}\text { Increased pleural fluid drainage; radiologic } \\
\text { improvement in } 75 \% \text { of patients; clinical improvement } \\
\text { in } 67 \% \text { of patients }\end{array}$ \\
\hline Bouros et $\mathrm{al}^{29}$ & Cohort, single-center & 20, streptokinase & $\begin{array}{l}\text { Increased pleural fluid drainage; excellent or moderate } \\
\text { radiologic improvement occurred in } 85 \% \text { of patients; safe }\end{array}$ \\
\hline Pollak et $\mathrm{al}^{30}$ & Cohort, single-center & 8 , urokinase & $\begin{array}{l}\text { Radiologic and clinical resolution or improvement } \\
\text { in } 89 \% \text { of cases; safe }\end{array}$ \\
\hline Robinson et $\mathrm{a}^{31}$ & $\begin{array}{l}\text { Cohort, single-center; } \\
\text { some patients were children }\end{array}$ & 13 , urokinase & Radiologic and clinical resolution in $77 \%$ of patients; safe \\
\hline Taylor et $\mathrm{al}^{32}$ & $\begin{array}{l}\text { Prospective uncontrolled, } \\
\text { single-center }\end{array}$ & II, streptokinase & $\begin{array}{l}\text { Increased pleural fluid drainage in all patients; } \\
\text { re-expansion of lung occurred in } 73 \% \text { of patients }\end{array}$ \\
\hline Cohen et $\mathrm{a}^{33}$ & Case reports & 2, urokinase & Resolution of loculated effusions in both patients \\
\hline Moulton et al ${ }^{34}$ & Retrospective & I I8 (98 adjunctive urokinase) & Increased pleural fluid drainage in $94 \%$ of patients; safe \\
\hline Laisaar et $\mathrm{a}^{35}$ & Cohort, single-center & 28 , streptokinase & $\begin{array}{l}\text { Seventy-two percent had excellent resolution } \\
\text { of pleural space collection }\end{array}$ \\
\hline Temes et $\mathrm{a}^{36}$ & Cohort, two centers & $\begin{array}{l}26, \text { streptokinase } \\
\text { or urokinase }\end{array}$ & $\begin{array}{l}\text { Sixty-two percent of patients had complete resolution } \\
\text { of symptoms and complete or near complete radiologic } \\
\text { resolution; safe }\end{array}$ \\
\hline Bouros et $\mathrm{al}^{37}$ & Uncontrolled, prospective & 20 , urokinase & $\begin{array}{l}\text { Increased pleural fluid drainage in all patients; } \\
\text { excellent radiologic improvement in } 65 \% \text { of patients; safe }\end{array}$ \\
\hline Jerjes et $\mathrm{a}^{38}$ & $\begin{array}{l}\text { Prospective, } \\
\text { uncontrolled, multicenter }\end{array}$ & $\begin{array}{l}48 \text { ( } 30 \text { with empyema), } \\
\text { streptokinase }\end{array}$ & $\begin{array}{l}\text { Ninety-two percent of patients had complete resolution } \\
\text { of pleural collection and adequate radiologic and } \\
\text { spirometric improvement; safe }\end{array}$ \\
\hline Roupie et $\mathrm{a}^{39}$ & $\begin{array}{l}\text { Retrospective } \\
\text { review, single-center }\end{array}$ & 16, streptokinase & $\begin{array}{l}\text { Increased pleural fluid drainage in all patients; complete } \\
\text { radiologic resolution observed in } 87 \% \text { of patients; safe }\end{array}$ \\
\hline Bilaceroglu et $\mathrm{a}^{40}$ & $\begin{array}{l}\text { Controlled, } \\
\text { randomized }\end{array}$ & $\begin{array}{l}\text { 128, urokinase or } \\
\text { streptokinase or } \\
\text { control saline }\end{array}$ & $\begin{array}{l}\text { Increased pleural fluid drainage and radiologic } \\
\text { improvement in urokinase group compared with } \\
\text { streptokinase or saline groups }\end{array}$ \\
\hline Bouros et $\mathrm{al}^{41}$ & Prospective, double-blind & $\begin{array}{l}50, \text { streptokinase } \\
\text { or urokinase }\end{array}$ & $\begin{array}{l}\text { Increased pleural fluid drainage occurred in both } \\
\text { urokinase and streptokinase groups; clinical } \\
\text { and radiologic improvement occurred in } 92 \% \\
\text { of patients in each group }\end{array}$ \\
\hline Chin et $\mathrm{al}^{42}$ & $\begin{array}{l}\text { Prospective, controlled } \\
\text { trial, compared adjuvant } \\
\text { streptokinase with closed } \\
\text { chest tube drainage }\end{array}$ & 52, streptokinase & $\begin{array}{l}\text { Streptokinase increased volume of fluid drained, } \\
\text { but did not reduce morbidity and mortality }\end{array}$ \\
\hline Davies et $\mathrm{al}^{43}$ & $\begin{array}{l}\text { Randomized controlled } \\
\text { trial compared intrapleural } \\
\text { streptokinase with saline }\end{array}$ & 24, streptokinase & $\begin{array}{l}\text { Streptokinase caused increased pleural fluid drainage } \\
\text { and greater improvement on chest radiographs } \\
\text { compared with saline; streptokinase was safe }\end{array}$ \\
\hline Wait et $\mathrm{al}^{44}$ & $\begin{array}{l}\text { Randomized trial of VATS } \\
\text { versus pleural drainage and } \\
\text { fibrinolytic therapy }\end{array}$ & 20, streptokinase & $\begin{array}{l}\text { VATS associated with a higher treatment success, } \\
\text { shorter hospital stay, and less cost }\end{array}$ \\
\hline
\end{tabular}


Table I (Continued)

\begin{tabular}{|c|c|c|c|}
\hline Reference & Type of study & $\begin{array}{l}\text { Patients }(\mathbf{n}) \text {, } \\
\text { agent used }\end{array}$ & Outcome \\
\hline Bouros et $\mathrm{al}^{45}$ & $\begin{array}{l}\text { Randomized, double-blind } \\
\text { study of urokinase } \\
\text { versus saline }\end{array}$ & $3 \mathrm{I}$, urokinase & $\begin{array}{l}\text { Urokinase group drained more pleural fluid and } \\
\text { had better clinical and radiologic improvement }\end{array}$ \\
\hline Lim et $\mathrm{al}^{46}$ & $\begin{array}{l}\text { Nonrandomized, } \\
\text { prospective, controlled } \\
\text { time series }\end{array}$ & $\begin{array}{l}82 \text { (streptokinase with tube } \\
\text { drainage } 29, \text { streptokinase } \\
\text { with early surgical drainage } \\
30) ; 44 \text { ( } 22 \text { streptokinase }\end{array}$ & $\begin{array}{l}\text { Streptokinase with early surgical drainage was } \\
\text { associated with less mortality and shorter hospitalization }\end{array}$ \\
\hline Diacon et $\mathrm{al}^{47}$ & $\begin{array}{l}\text { Randomized, controlled, } \\
\text { single-center }\end{array}$ & and 22 normal saline) & $\begin{array}{l}\text { Streptokinase caused higher clinical success rate } \\
\text { and reduced rate of surgical referrals; no difference } \\
\text { in mortality }\end{array}$ \\
\hline Maskell et $\mathrm{al}^{48}$ & $\begin{array}{l}\text { Double-blind randomized } \\
\text { trial, } 52 \text { centers }\end{array}$ & $\begin{array}{l}\text { Streptokinase } 207 \\
\text { and placebo } 226\end{array}$ & $\begin{array}{l}\text { Streptokinase did not reduce mortality or rate } \\
\text { of surgery or length of hospitalization; serious adverse } \\
\text { effects more in streptokinase groups }\end{array}$ \\
\hline
\end{tabular}

Abbreviation: VATS, video-assisted thoracoscopic surgery.

with regard to the proportion of those who died or needed surgery (relative risk 1.14; (95\% confidence interval [CI] $0.85-1.54 ; P=0.43) .{ }^{48}$ Regarding the secondary endpoints, there was no benefit from streptokinase in terms of mortality, rate of surgery, radiographic outcome, or length of hospital stay. ${ }^{48}$

\section{Intrapleural fibrinolysis versus surgery in adults}

One small trial has directly compared medical and surgical treatment of complicated PPEs and empyema. Wait et al compared tube thoracostomy and fibrinolytic therapy with VATS in a prospective randomized trial. ${ }^{44}$ Twenty patients aged 18 years or older with parapneumonic empyema were randomized to receive either three doses of 250,000 $\mathrm{U}$ each of streptokinase administered via tube thoracostomy or VATS. The overall mortality rate was $20 \%$ and was divided equally between the streptokinase and VATS groups. However, the VATS group had significantly higher primary treatment success (measured as lung expansion), fewer days of chest tube drainage, and fewer total hospital days. Of importance, all the streptokinase treatment failures (five of nine patients) were successfully treated with VATS ${ }^{44}$ However, the results of this study need to be interpreted in the light of the small sample size and the unusually high failure rate $(55 \%)$ in the medically treated limb. Further appropriately powered studies are clearly needed to compare surgical and medical treatment of complicated PPEs and empyema. Until such studies become available, it is not possible to make definite recommendations on the preferability of primary management approaches of pleural space sepsis in adults. Generally, patients with frank empyema and/or loculations at presentation are more likely to require surgery. ${ }^{14,15}$
Another point of importance is the timing of sequential surgical drainage approaches, which has probably varied widely among the published studies. ${ }^{14}$ In a nonrandomized, prospective, controlled time series, Lim et al have shown that early surgery provided advantages in patients not responding rapidly to intrapleural fibrinolysis, but the radiologic assessment performed before drainage was not fully described.$^{46} \mathrm{In}$ fact, to this time, there are no established objective criteria that define the point at which a patient should be operated on. Patients should be considered for surgery if they have residual sepsis and persistent pleural collection despite drainage. ${ }^{14,15}$ Failure of sepsis to begin to resolve within seven days is suggested as an appropriate period after which an opinion from a surgeon should be sought. ${ }^{15}$

It is clear that in spite of guideline recommendations for the use of intrapleural fibrinolytic therapy for pleural space sepsis in adults, ${ }^{14,15}$ clinical evidence of benefit remains marginal. Further support for the lack of evidence of benefit with intrapleural fibrinolytic therapy is found in a recent review performed by the Cochrane collaboration that describes existing data as incomplete and suggests that results should be treated with caution because the benefit of intrapleural fibrinolytic therapy has not been significant in the subgroup of high-quality studies. ${ }^{51}$

\section{Intrapleural fibrinolytic therapy in children}

In children, 10 studies of the use of intrapleural fibrinolytic therapy in a total of 297 patients have been published and are summarized in Table 2. ${ }^{51-60}$ Published studies in children employed intrapleural urokinase, streptokinase, and tPA as fibrinolytic agents. Urokinase on its own was used in 
six studies, ${ }^{52-55,57,59}$ whereas streptokinase alone was used in one study ${ }^{51}$ and tPA alone in one trial. ${ }^{60}$ One retrospective study compared urokinase with alteplase and reported a treatment success rate of $98 \%$ for alteplase and 100\% for urokinase, but patients who received alteplase drained more pleural fluid. ${ }^{58}$

Like in adults, most of the studies in children were uncontrolled observational reports with clear methodic limitations. ${ }^{51-54,56-58}$ Five studies used amount of pleural fluid drained as the endpoint, and none of these studies was controlled. ${ }^{51,52,54,56,58}$ In three of these five studies, increased pleural fluid drainage resulted in complete resolution of empyema, clinical improvement, or clinical success. ${ }^{51,54,58}$ It is of note that none of the studies in children demonstrated reduction in mortality with the use of intrapleural fibrinolytic therapy. The use of intrapleural fibrinolysis in children was found to be safe in seven studies, ${ }^{51-54,56-58}$ and none of the pediatric studies reported serious adverse effects.

\section{Intrapleural fibrinolysis versus surgery in children}

Two prospective, randomized trials in children compared thoracoscopic decortication with tube thoracostomy and fibrinolysis for empyema. 59,60 Their findings were similar. Sonnappa et al randomized 60 children with empyema to receive either a percutaneous chest drain with intrapleural urokinase or primary VATS. ${ }^{59}$ No significant difference between the two groups was found in length of hospital stay after intervention, total hospital stay, or radiologic outcome at six months after intervention. However, the treatment costs for patients in the urokinase arm were significantly lower than those for the VATS arm. ${ }^{59}$ St Peter et al studied 36 patients who were randomized to receive either three doses of tPA $4 \mathrm{mg}$ via a chest tube or decortication via VATS. ${ }^{60}$ There was no difference for days of hospitalization after intervention, days of need for oxygen, days until afebrile, or analgesic requirements. VATS was associated with significantly higher costs. Three patients in the fibrinolysis group subsequently required VATS, and two in the VATS group required ventilatory support, one of whom required temporary dialysis. ${ }^{60}$ It can be concluded from these two studies that there is no difference in clinical outcome between intrapleural fibrinolysis and VATS for the treatment of childhood empyema. Intrapleural fibrinolysis is a more cost-effective treatment option compared with VATS, and should be the primary treatment of choice in children.

\section{Intrapleural DNase}

Although streptokinase lyses adhesions, it does not reduce pus viscosity. ${ }^{61}$ It is possible that a combination of agents that

Table 2 Summary of intrapleural fibrinolysis studies in children

\begin{tabular}{|c|c|c|c|}
\hline Reference & Type of study, settings & Patients (n), agent used & Outcome \\
\hline Rosen et $\mathrm{al}^{51}$ & Retrospective, single-center & 5, streptokinase & $\begin{array}{l}\text { All empyemas resolved, patients improved } \\
\text { clinically and drained more pleural fluid; safe }\end{array}$ \\
\hline Stringel et $\mathrm{al}^{52}$ & Case reports & 2, urokinase & Increased pleural fluid drainage; safe \\
\hline Kornecki et $\mathrm{al}^{53}$ & Case series, single-center & 7, urokinase & $\begin{array}{l}\text { Complete resolution of empyema was } \\
\text { attained in } 86 \% \text { of patients; safe }\end{array}$ \\
\hline Krishnan et $\mathrm{al}^{54}$ & Cohort, single-center & I4, urokinase & $\begin{array}{l}\text { All patients had increased pleural fluid } \\
\text { drainage and resolution of symptoms; safe }\end{array}$ \\
\hline Thomson et $\mathrm{al}^{55}$ & $\begin{array}{l}\text { Double-blind, randomized, } \\
\text { urokinase versus saline, } 10 \text { centers }\end{array}$ & 60 , urokinase & Significantly shortened hospital stay \\
\hline Kilic et $\mathrm{al}^{56}$ & Case series, single-center & $\begin{array}{l}25 \text { ( } 17 \text { urokinase } \\
\text { and } 8 \text { streptokinase) }\end{array}$ & $\begin{array}{l}\text { In } 80 \% \text { of patients there was increased } \\
\text { pleural fluid drainage and almost complete } \\
\text { resolution on chest radiography or } \\
\text { ultrasonography; safe }\end{array}$ \\
\hline Barbato et $\mathrm{al}^{57}$ & $\begin{array}{l}\text { Uncontrolled retrospective } \\
\text { study, single-center; I } 7 \text { patients } \\
\text { received urokinase compared with } \\
\text { I I historic patients }\end{array}$ & I7, urokinase & $\begin{array}{l}\text { Seventy percent of patients improved; } \\
\text { shortened hospital stay; safe }\end{array}$ \\
\hline Wells et $\mathrm{al}^{58}$ & $\begin{array}{l}\text { Retrospective review, } \\
\text { hospital based }\end{array}$ & 7I, urokinase or alteplase & $\begin{array}{l}\text { Treatment success was } 98 \% \text { for alteplase } \\
\text { and } 100 \% \text { for urokinase; alteplase patients } \\
\text { drained more fluid; safe }\end{array}$ \\
\hline Sonnappa et $\mathrm{al}^{59}$ & $\begin{array}{l}\text { Prospective randomized } \\
\text { trial, single-center }\end{array}$ & $\begin{array}{l}60 \text { (30 urokinase } \\
\text { versus } 30 \text { VATS) }\end{array}$ & $\begin{array}{l}\text { Urokinase is equally efficacious as VATS, but } \\
\text { a more cost-effective treatment }\end{array}$ \\
\hline St Peter et $\mathrm{al}^{60}$ & Prospective, randomized & 36, VATS versus tPA & $\begin{array}{l}\text { tPA is equally efficacious as VATS, but a more } \\
\text { cost-effective treatment }\end{array}$ \\
\hline
\end{tabular}

Abbreviation: VATS, video-assisted thoracoscopic drainage. 
reduces pus viscosity and breakdown of loculations may be more effective in draining the infected pleural space. It is interesting that Tillett and Sherry used two streptococcal products in their original work, published more than 60 years ago, on the use of intrapleural therapy for the treatment of empyema, ie, streptokinase (used as fibrinolysin) and streptococcal deoxyribonuclease (used as a depolymerizer of deoxyribonucleoprotein that is abundant in purulent empyematous fluid). ${ }^{20}$ Recently there has been an interest in intrapleural DNase as a possible candidate to reduce pus viscosity in combination with thrombolytic therapy to enhance pus drainage. ${ }^{61}$ In an animal model, the combination of recombinant tPA (alteplase) and recombinant human deoxyribonuclease (rhDNase) has been shown to be more effective in treating empyema than either agent used alone. ${ }^{62}$ Successful treatment of human empyema with intrapleural rhDNase given after intrapleural fibrinolytic therapy has been described in at least one case report. ${ }^{63}$

A multicenter, randomized trial of intrapleural tPA and DNase in pleural infection has recently been completed, but is currently only reported in abstract form. ${ }^{64}$ Two hundred and ten patients with pleural space infection were randomized to receive double-matched placebo, active tPA plus active DNase, active tPA plus placebo DNase, or placebo tPA plus active DNase for three days. Combination intrapleural tPA/ DNase was significantly superior to the other combinations in improving pleural fluid drainage (95\% CI 5\%-22.9\%; $P=0.002)$. DNase alone appears to be associated with increased frequency of surgery and/or death. The proportion of patients dying or requiring surgery for their infection was higher in the DNase plus placebo group and similar in all other groups (number of deaths or surgery tPA/DNase 17.3\%; placebo/placebo $12.7 \%$; tPA/placebo $15.4 \%$; DNase/placebo $\left.45.1 \%, X^{2} 3 ; P=0.0001\right) .{ }^{64}$ A peer-reviewed full report of this trial is awaited.

\section{Conclusion}

Empyema thoracis is a cause of high mortality, and its occurrence is increasing in both children and adults. BTS and ACCP guidelines recommend the use of intrapleural fibrinolysis in adults and children with complicated PPEs or empyema if they are not improving, have thick pus, or have pleural loculations, but the evidence for their benefit is low. Published reports on the use of intrapleural fibrinolysis for the treatment of complicated PPEs and empyema suffer many methodologic and design limitations. Nevertheless, these reports have not shown a survival advantage with the use of intrapleural fibrinolysis in adults. However, intrapleural fibrinolysis is safe in most of the published studies, has been shown to enhance drainage of infected pleural fluid, and may still be used in adults who have large collections impeding breathing, but a proportion of these patients will ultimately need surgery for a definite cure. Streptokinase seems to be as effective as urokinase in enhancing drainage of infected pleural fluid in adults. There is emerging evidence that a combination of intrapleural tPA/DNase is significantly superior to tPA or DNase alone or placebo in improving pleural fluid drainage in adults with pleural space infection. In children, intrapleural thrombolysis has not been shown to reduce mortality, but has been shown to enhance drainage of infected pleural fluid. Intrapleural urokinase was shown to be marginally better when compared with alteplase in treating pleural space sepsis. Two prospective, randomized trials have shown that there is no difference in clinical outcome between intrapleural fibrinolysis and VATS for the treatment of childhood empyema. Intrapleural fibrinolysis is a more cost-effective treatment option compared with VATS and should be the primary treatment of choice in children.

\section{Disclosure}

The authors report no conflicts of interest in this work.

\section{References}

1. Davies CW, Kearney SE, Gleeson FV, Davies RJ. Predictors of outcome and longterm survival in patients with pleural infection. Am J Respir Crit Care Med. 1999;160:1682-1687.

2. Ahmed AH, Yacoub TE. Empyema thoracis. Clin Med Insights Circ Respir Pulm Med. 2010;4:1-8.

3. Light RW, Girard WM, Jenkinson SG, George RB. Parapneumonic effusions. Am J Med. 1980;69:507-512.

4. Lim WS, Lewis S, Macfarlane JT. Severity prediction rules in community acquired pneumonia: A validation study. Thorax. 2000;55:219-223

5. Taryle DA, Potts DE, Sahn SA. The incidence and clinical correlates of parapneumonic effusions in pneumococcal pneumonia. Chest. 1978;74:170-173.

6. Hasley PB, Albaum MN, Li YH, et al. Do pulmonary radiographic findings at presentation predict mortality in patients with communityacquired pneumonia? Arch Intern Med. 1996;156:2206-2212.

7. Andrews NC, Parker EF, Shaw RP, et al. Management of nontuberculous empyema. Am Rev Respir Dis. 1962;85:935-936.

8. Heffner JE, Brown LK, Barbieri C, Barbieri C, Deleo JM. Pleural fluid chemical analysis in parapneumonic effusions. A meta-analysis. Am J Respir Crit Care Med. 1995;151:1700-1708.

9. Chapman SJ, Davies RJ. Recent advances in parapneumonic effusions and empyema. Curr Opin Pulm Med. 2004;10:299-304.

10. Kroegel C, Anthony VB. Immunobiology of pleural inflammation: Potential implications for pathogenesis, diagnosis and therapy. Eur Respir J. 1997;10:2411-2418.

11. Idell S, Girard W, Koenig KB, et al. Abnormalities of pathways of fibrin turnover in the human pleural space. Am Rev Respir Dis. 1991;144: 187-194.

12. Aleman C, Alegre J, Monasterio J, et al. Association between inflammatory mediators and the fibrinolysis system in infectious pleural effusions. Clin Sci (Lond). 2003;105:601-607.

13. Sahn SA, Reller LB, Taryle DA, et al. The contribution of leukocytes and bacteria to the low pH of empyema fluid. Am Rev Respir Dis. 1983; 128:811-815. 
14. Colice GL, Curtis A, Deslauriers J, et al. Medical and surgical treatment of parapneumonis effusions: Evidence-based guideline. Chest. 2000; 118:1158-1171.

15. Davies CWH, Gleeson FV, Davies RJO. BTS guidelines for the management of pleural infection. Thorax. 2003;58:ii18-ii28.

16. Balfour-Lynn IM, Abrahamson E, Cohen G, et al. Paediatric Pleural Diseases Subcommittee of the BTS Standards of Care Committee. BTS guidelines for the management of pleural infection in children. Thorax. 2005;60:i1-i21.

17. Doggrell SA. Alteplase: Descendancy in myocardial infarction, ascendancy in stroke. Expert Opin Investig Drugs. 2001;10:2013-2029.

18. Bhattacharya SK, Sen P, Ray A, Das P, editors. Pharmacology. 2nd ed. New Delhi: Elsevier, Reed Elsevier India Private Limited; 2005.

19. Iqbal O, Messmore H, Hoppensteadt D, Fareed J, Wehrmacher W. Thrombolytic drugs in acute myocardial infarction. Clin Appl Thromb Hemost. 2000;6:1-13.

20. Tillett WS, Sherry S. The effect in patients of streptococcal fibrinolysin (streptokinase) and streptococcal desoxyribonuclease on fibrinous, purulent, and sanguinous pleural exudations. J Clin Invest. 1949;28: 173-190.

21. Bergh NP, Ekroth R, Larsson S, et al. Intrapleural streptokinase in the treatment of hemothorax and empyema. Scand J Thorac Cardiovasc Surg. 1977;11:265-268.

22. Fraedrich G, Hofmann D, Effenhauser P, et al. Instillation of fibrinolytic enzymes in the treatment of pleural empyema. Thorac Cardiovasc Surg. 1982;30:36-38

23. Mitchell ME, Alberts WM, Chandler KW, et al. Intrapleural streptokinase in management of parapneumonic effusions. Report of series and review of literature. J Fla Med Assoc. 1989;76:1019-1022.

24. Moulton JS, Moore PT, Mencini RA. Treatment of loculated pleural effusions with transcatheter intracavitary urokinase. Am J Roentgenol. 1989;153:941-945.

25. Willsie Ediger SK, Salzman G, Reisz G, et al. Use of intrapleural streptokinase in the treatment of thoracic empyema. Am J Med Sci. 1990;300:296-300.

26. Aye RW, Froese DP, Hill LD. Use of purified streptokinase in empyema and hemothorax. Am J Surg. 1991;161:560-562.

27. Lee KS, Im JG, Kim YH, et al. Treatment of thoracic multiloculated empyemas with intracavitary urokinase: A prospective study. Radiology. 1991;179:771-775.

28. Henke CA, Leatherman JW. Intrapleurally administered streptokinase in the treatment of acute loculated non purulent parapneumonic effusions. Am Rev Respir Dis. 1992;145:680-684.

29. Bouros D, Schiza S, Panagou P, et al. Role of streptokinase in the treatment of acute loculated parapneumonic pleural effusions and empyema. Thorax. 1994;49:852-855.

30. Pollak JS, Passik CS. Intrapleural urokinase in the treatment of loculated pleural effusions. Chest. 1994;105:868-873.

31. Robinson LA, Moulton AL, Fleming WH, et al. Intrapleural fibrinolytic treatment of multiloculated thoracic empyemas. Ann Thorac Surg. 1994;57:803-813.

32. Taylor RFH, Rubens MB, Pearson MC, et al. Intrapleural streptokinase in the management of empyema. Thorax. 1994;49:856-859.

33. Cohen ML, Finch IJ. Transcatheter intrapleural urokinase for loculated pleural effusion. Chest. 1994;105:1874-1876.

34. Moulton JS, Benkert RE, Weisiger KH, et al. Treatment of complicated pleural fluid collections with image-guided drainage and intracavitary urokinase. Chest. 1995;108:1252-1259.

35. Laisaar T, Puttsepp E, Laisaar V. Early administration of intrapleural streptokinase in the treatment of multiloculated pleural effusions and pleural empyemas. Thorac Cardiovasc Surg. 1996;44:252-256.

36. Temes RT, Follis F, Kessler RM, et al. Intrapleural fibrinolytics in management of empyema thoracis. Chest. 1996;110:102-106.

37. Bouros D, Schiza S, Tzanakis N, et al. Intrapleural urokinase in the treatment of complicated parapneumonic pleural effusions and empyema. Eur Respir J. 1996;9:1656-1659.
38. Jerjes Sanchez C, Ramirez Rivera A, Elizalde JJ, et al. Intrapleural fibrinolysis with streptokinase as an adjunctive treatment in haemothorax and empyema: A multicenter trial. Chest. 1996;109:1514-1519.

39. Roupie E, Bouabdallah K, Delclaux C, et al. Intrapleural administration of streptokinase in complicated purulent pleural effusion: A CT-guided strategy. Intensive Care Med. 1996;22:1351-1353.

40. Bilaceroglu S, Cagerici U, Cakan A. Management of complicated parapneumonic pleural effusions with image-guided drainage and intrapleural urokinase or streptokinase: A controlled randomized trial. Eur Respir J. 1997;10:325S.

41. Bouros D, Schiza S, Patsourakis G, et al. Intrapleural streptokinase versus urokinase in the treatment of complicated parapneumonic effusion. Am J Respir Crit Care Med. 1997;155:291-295.

42. Chin NK, Lim TK. Controlled trial of intrapleural streptokinase in the treatment of pleural empyema and complicated parapneumonic effusion. Chest. 1997;111:275-279.

43. Davies RJO, Traill ZC, Gleeson FV. Randomized controlled trial of intra-pleural streptokinase in community acquired pleural infection. Thorax. 1997;52:416-421.

44. Wait MA, Sharma S, Hohn J, et al. A randomised trial of empyema therapy. Chest. 1997;111:1548-1551.

45. Bouros D, Schiza A, Tzanakis N, et al. Intrapleural urokinase versus normal saline in the treatment of complicated para-pneumonic effusions and empyema. Am J Respir Crit Care Med. 1999;159:37-42.

46. Lim TK, Chin NK. Empirical treatment with fibrinolysis and early surgery reduces the duration of hospitalization in pleural sepsis. Eur Respir J. 1999;13:514-518.

47. Diacon AH, Theron J, Schuurmans MM, van de Wal BW, Bolliger CT. Intrapleural streptokinase for empyema and complicated parapneumonic effusions. Am J Respir Crit Care Med. 2004;170:49-53.

48. Maskell NA, Davies CWH, Nunn AJ, et al. UK controlled trial of intrapleural streptokinase for pleural infection. NEngl J Med. 2005;352: 865-874.

49. Strange C, Allen ML, Harley R, Lazarchick J, Sahn SA. Intrapleural streptokinase in experimental empyema. Am Rev Respir Dis. 1993;147: 962-966.

50. Cameron RJ, Davies HR. Intra-pleural fibrinolytic therapy versus conservative management in the treatment of adult parapneumonic effusions and empyema. Cochrane Database Syst Rev. 2008;2:CD002312.

51. Rosen H, Nadkarni V, Theroux M, et al. Intrapleural streptokinase as adjunctive treatment for persistent empyema in pediatric patients. Chest. 1993;103:1190-1193.

52. Stringel G, Hartman AR. Intrapleural instillation of urokinase in the treatment of loculated pleural effusions in children. J Pediatr Surg. 1994;29:1539-1540.

53. Kornecki A, Sivan Y. Treatment of loculated pleural effusion with intrapleural urokinase in children. J Pediatr Surg. 1997;32:1473-1475.

54. Krishnan S, Amin N, Dozor AJ, et al. Urokinase in the management of uncomplicated parapneumonic effusions in children. Chest. 1997; 112:1579-1583

55. Thomson AH, Hull J, Kumar R, et al. A randomised trial of intrapleural urokinase in the treatment of childhood empyema. Thorax. 2002;57: 343-347.

56. Kilic N, Celebi S, Gurpinar A, et al. Management of thoracic empyema in children. Pediatr Surg Int. 2002;18:21-23.

57. Barbato A, Panizzolo C, Monciotti C, et al. Use of urokinase in childhood pleural empyema. Pediatr Pulmonol. 2003;35:50-55.

58. Wells RG, Havens PL. Intrapleural fibrinolysis for parapneumonic effusion and empyema in children. Radiology. 2003;228:370-378.

59. Sonnappa S, Cohen G, Owens CM, et al. Comparison of urokinase and video-assisted thoracoscopic surgery for treatment of childhood empyema. Am J Respir Crit Care Med. 2006;174:221-227.

60. St Peter SD, Tsao K, Harrison C, et al. Thoracoscopic decortication vs tube thoracostomy with fibrinolysis for empyema in children: A prospective, randomized trial. J Pediatr Surg. 2009;44:106-111. 
61. Simpson G, Roomes D, Heron M. Effects of streptokinase and deoxyribonuclease on viscosity of human surgical and empyema pus. Chest. 2000;117:1728-1733.

62. Hawthorne ZZML, Guo Y, Drake W, Bilaceroglu S, Misra HL, Light RW. Tissue plasminogen activator combined with human recombinant deoxyribonuclease is effective therapy for empyema in a rabbit model. Chest. 2006;129:1577-1583.
63. Simpson G, Roomes D, Reeves B. Successful treatment of empyema thoracis with human recombinant deoxyribonuclease. Thorax. 2003;58: 365-366.

64. Rahman MM, Maskell N, Davies CWH, et al. Primary result of the second multicentre intrapleural sepsis (MIST2) trial; randomized trial of intrapleural tPA and DNase in pleural infection. Thorax. 2009;64 Suppl IV:A1.

\section{Publish your work in this journal}

Clinical Pharmacology: Advances and Applications is an international, peer-reviewed, open access journal publishing original research, reports, reviews and commentaries on all areas of drug experience in humans The manuscript management system is completely online and includes a very quick and fair peer-review system, which is all easy to use.
Visit http://www.dovepress.com/testimonials.php to read real quotes from published authors.

\footnotetext{
Submit your manuscript here: http://www.dovepress.com/clinical-pharmacology-advances-and-applications-journal
} 